\title{
Sistem Informasi Perpustakaan Menggunakan Metode Waterfall
}

\author{
Mely Mailasari ${ }^{[1]}$, Erma Delima Sikumbang ${ }^{[2]}$ \\ Program Studi Sistem Informasi, Universitas Bina Sarana Informatika ${ }^{[1]}$ \\ Program Studi Sistem Informasi Akuntansi, Universitas Bina Sarana Informatika ${ }^{[2]}$ \\ Jl. Kamal Raya No. 18, Ringroad Barat Cengkareng Jakarta Barat, 021-54376399 \\ mely.myl@bsi.ac.id ${ }^{[1]}$,erma@bsi.ac.id ${ }^{[2]}$
}

\begin{abstract}
Abstrak- Sistem perpustakaan yang berjalan di SMP Negeri 3 Kota Bekasi masih menggunakan metode konvensional, dimana cara pencarian, peminjaman, dan pengembalian masih menggunakan sistem pencarian secara manual, seperti sistem peminjaman dan pengembalian yang masih mengunakan sistem tulis tangan pada buku besar. Sering kali buku yang akan dipinjam oleh siswa tidak dapat diperoleh walaupun buku tersebut ada di perpustakaan itu. Hal ini, mengakibatkan berkurangnya efektivitas dan efisiensi terhadap layanan perpustakaan. Dari permasalahan tersebut maka perlu dibuat sebuah pengembangan sistem menggunakan metode penelitian waterfall yang prosesnya terstruktur sehingga kualitas sistem yang dihasilkan baik. Sistem yang dihasilkan dalam penelitian ini adalah sistem informasi perpustakaan berbasis web menggunakan bahasa pemrograman PHP dan database MySQL. Sistem informasi yang diharapkan dapat mempermudah pengolahan data perpustakaan dan meningkatkan pelayanan perpustakaan pada SMP Negeri 3 Kota Bekasi. Hasil penelitian ini akan diujikan menggunakan blackbox testing.
\end{abstract}

Kata Kunci- sistem informasi, perpustakaan, berbasis web

\section{PENDAHULUAN}

Perpustakaan pada umumnya seperti gudang buku, dimana buku-buku, jurnal, hasil penelitian dan majalah berada di rakrak yang tertata dengan sangat rapi. Sehingga membacanya harus datang ke perpustakaan dan mencari buku yang diinginkan[1].

Perpustakaan sebagai salah satu bagian dari tempat pendidikan mempunyai peranan yang sangat penting untuk menambah wawasan dan pengetahuan pelajar. Bermacammacam sumber informasi ilmiah, buku-buku, literatur, dari segala jenis media perpustakaan, mampu disebarluaskan dengan sistem tertentu[2].

Perpustakaan sekolah misalnya menjadi salah satu sumber belajar tetapi bukan satu-satunya. Segala bahan pustaka yang dimiliki perpustakaan sekolah harus dapat menunjang proses belajar mengajar maka pengadaan buku perpustakaan hendaknya mempertimbangkan kurikulum sekolah juga sesuai dengan tujuan pendidikan nasional dan untuk mengikuti perkembangan Ilmu Pengetahuan dan Teknologi (IPTEK) yang maju pesat[3].

Penelitian oleh Rosita Cahyaningtyas dan Siska Iriyani (2015) pada SMP Negeri Tulakan, saat siswa ingin meminjam buku untuk keperluan pembelajaran, petugas perpustakaan harus melakukannya secara manual dengan cara penulisan dibuku peminjaman. Agar pelayanan lebih efektif dan efisien perlu adanya pembenahan sistem pelayanan yang berawal dari manual berkembang menjadi sistem pelayanan dengan menggunakan program khusus, sehingga membutuhkan sistem informasi perpustakaan berbasis IT. Agar sebuah perancangan menyediakan informasi tidak menyimpang dari tujuan sebenarnya[3].

Hal yang samapun sistem perpustakaan yang berjalan di SMP Negeri 3 Kota Bekasi masih bersifat konvensional, dimana pencarian, peminjaman, dan pengembalian masih menggunakan sistem pencarian secara manual, seperti sistem peminjaman dan pengembalian yang masih menggunakan sistem tulis tangan pada buku besar. Sering kali buku yang akan dipinjam oleh siswa tidak dapat diperoleh walaupun buku tersebut ada di perpustakaan itu. Hal ini terjadi karena sistem pencarian buku masih manual.

Oleh karena itu, dari masalah diatas dibuatlah suatu sistem pengolahan data perpustakaan untuk meningkatkan pelayanan bagi para murid disekolah tersebut dan keefisienan aktivitas kerja serta dapat menghasilkan sebuah informasi yang bersifat akurat.

Perubahan bentuk pengolahan data perpustakaan yang manual ke pengolahan data yang berbasis komputer menjadi solusi untuk mengatasi keterlambatan informasi dan kesulitan pengelolaan detail data koleksi buku-buku yang ada. Dengan perkembangan teknologi komunikasi data, sistem informasi perpustakaan sekolah dapat dibangun sebagai sistem informasi perpustakaan online berbasis web[4].

Sistem informasi perpustakaan adalah proses komputerisasi untuk mengolah data dalam suatu perpustakaan. Semua diproses menggunakan software tertentu seperti software pengolah database. Petugas perpustakaan dapat selalu memonitor tentang ketersediaan buku, daftar buku baru, peminjaman buku dan pengembalian buku. Jadi dibandingkan dengan perpustakaan konvensional, sistem informasi perpustakaan lebih memudahkan pegawai perpustakaan dan pengguna perpustakaan dalam mengelola dan meminjam buku[5].

Sistem informasi perpustakaan ini dibuat dengan menggunakan software dreamweaver dan menggunakan database MySQL.

ISSN : 2301-7988

E-ISSN : 2581-0588

DOI : $10.32736 /$ sisfokom.v8i2.657 


\section{METODE PENELITIAN}

\section{A. Metode Pengembangan Perangkat Lunak}

Model waterfall adalah model klasik yang bersifat sistematis, berurutan dalam membangun software. Nama model ini sebenarnya adalah Linear Sequential Model dan sering disebut classic life cycle atau metode waterfall. Disebut waterfall karena tahap demi tahap yang dilalui harus menunggu selesinya tahap sebelumnya dan berjalan berurutan[6]. Fase-fase dalam Waterfall Model digambarkan sebagi berikut:

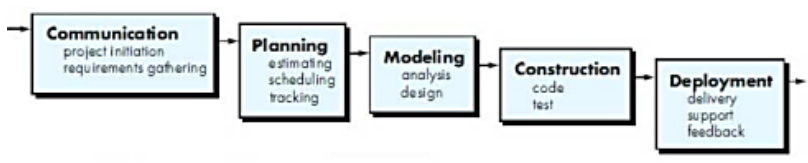

Gambar 1. Model Waterfall

Fase-fase tersebut dpat diuraikan sebagai berikut:

1) Communication (Project Initiation \& Requirement Gathering)

Menganalisa permasalahan yang dihadapi dan mengumpulkan data-data yang diperlukan seperti data anggota, data buku, data peminjaman buku, dan data pengembalian buku

2) Planning (Estimating, Scheduling, Tracking)

Tahap berikutnya adalah tahapan perencanaan yang menjelaskan tentang estimasi tugas-tugas teknis yang dilakukan, resiko-resiko yang dapat terjadi, sumber daya yang diperlukan dalam membuat sistem, produk kerja yang ingin dihasilkan, penjadwalan kerja yang kan dilaksanakan dan tracking proses pengerjaan sistem.

3) Modeling (Analysis \& Design)

Tahap desain sistem informasi perpustakaan berbasis web dalam perancangan ini menggunakan Entity Relationship Diagram (ERD), Struktur Navigasi berdasarkan hasil pengumpulan informasi dan analisa kebutuhan pengguna. ERD adalah bentuk pling wal dalam melkukn perancangan basis data relasional[7]. Sedangkan Struktur Navigasi adlh gabungan dari struktur reprsentasi informsi situs web dan mekanisme link yang mendukung pengunjung untuk melakukan penjeljahan situs[8].

4) Construction (Code \& Test)

Desain harus ditranslasikan ke dalam program perangkat lunak. Hasil dari tahap ini adalah program komputer sesuai dengan desain yng sudah dibuat. Bahasa pemrograman yang digunakan dalam pembuatan sistem informasi perpustakaan ini adalah bahasa PHP dengan basis data MySQL.

5) Deployment (Delivery, Support, Feedback)

Pada tahapan ini sistem informasi perpustakaan dilakukan uji coba kepada user yaitu dalam penelitian ini SMP Negeri 3 Kota Bekasi kemudian pemeliharaan sistem secara berkala, perbaikan sistem, evaluasi sistem.

\section{B. Teknik pengumpulan Data}

Teknik pengumpulan data yang digunakan dalam melakukan pengumpulan data untuk penelitian adalah:

1) Observasi

Penulis melihat dan mengamati semua permasalahan di perpustakaan SMP Negeri 3 Kota Bekasi untuk mengetahui untuk apa di buatkan sistem perpustakaan.

2) Wawancara

Penulis mengumpulkan data secara langsung dengan Ibu Susilawati selaku pengelola perpustakaan tentang penataan buku, permasalahan yang terjadi di SMP Negeri 3 Kota Bekasi.

3) Studi Pustaka

Dalam metode ini penulis mengumpulkan dan memperoleh data dengan cara membaca dan mempelajari buku-buku referensi untuk mencari data-data dari sumber yang berhubungan dengan penulisan penelitian.

\section{HASIL DAN PEMBAHASAN}

Penelitian ini merujuk penelitian terdahulu yang digambarkan dalam tabel sebagai berikut:

Tabel 1. Penelitian Terdahulu

\begin{tabular}{|c|c|c|c|c|}
\hline No. & $\begin{array}{l}\text { Judul Jurnal } \\
\text { dan Peneliti }\end{array}$ & $\begin{array}{c}\text { Tahun dan } \\
\text { Tempat } \\
\text { Penelitian }\end{array}$ & $\begin{array}{c}\text { Metode } \\
\text { Penelitian }\end{array}$ & Hasil Penelitian \\
\hline 1. & $\begin{array}{l}\text { Pembuatan } \\
\text { Sistem } \\
\text { Informasi } \\
\text { Perpustakaan } \\
\text { Berbasis } \\
\text { Website Pada } \\
\text { Sekolah } \\
\text { Menegah } \\
\text { Pertama } \\
\text { Negeri } 1 \\
\text { Donorojo } \\
\text { Kabupaten } \\
\text { Pacitan, oleh } \\
\text { Dani Eko } \\
\text { Hendrianto }\end{array}$ & $\begin{array}{l}\text { 2014, Sekolah } \\
\text { Menegah } \\
\text { Pertama } \\
\text { Negeri } \\
\text { Donorojo }\end{array}$ & Kuantitatif & $\begin{array}{l}\text { Hasil penelitian } \\
\text { ini membuat } \\
\text { sistem informasi } \\
\text { perpustakaan } \\
\text { berbasis website } \\
\text { untuk } \\
\text { meningkatkan } \\
\text { pelayanan dan } \\
\text { kinerja petugas } \\
\text { perpustakaan } \\
\text { dalam hal } \\
\text { pengelolaan data } \\
\text { administrasi } \\
\text { perpustakaan serta } \\
\text { mempercepat } \\
\text { transaksi } \\
\text { peminjaman dan } \\
\text { pengembalian } \\
\text { buku oleh } \\
\text { siswa.[15] }\end{array}$ \\
\hline 2. & $\begin{array}{l}\text { Sistem } \\
\text { Manajemen } \\
\text { Perpustakaan } \\
\text { (Online) Pada } \\
\text { SMP Empat } \\
\text { Lima } 2 \\
\text { Kedungpring } \\
\text { Lamongan, } \\
\text { Oleh Siti } \\
\text { Mujilahwati, } \\
\text { Sabilal } \\
\text { Muhtadin }\end{array}$ & $\begin{array}{l}2014, \quad \text { SMP } \\
\text { Empat Lima } 2 \\
\text { Kedungpring }\end{array}$ & Kuantitatif & $\begin{array}{l}\text { Penelitian ini } \\
\text { menghasilkan } \\
\text { sistem } \\
\text { perpustakaan } \\
\text { online yang dapat } \\
\text { membantu } \\
\text { mengatur } \\
\text { penempatan } \\
\text { koleksi digital } \\
\text { serta transaksi } \\
\text { peminjaman yang } \\
\text { ada } \\
\text { diperpustakaan.[1 } \\
\text { 4] }\end{array}$ \\
\hline 3. & $\begin{array}{l}\text { Konsep Dasar } \\
\text { Manajemen } \\
\text { Perpustakaan } \\
\text { Dalam } \\
\text { Mewujudkan } \\
\text { Mutu Layanan } \\
\text { Prim Dengan }\end{array}$ & 2014 & Kuantitatif & $\begin{array}{l}\text { Pada penelitian ini } \\
\text { dijelaskan konsep } \\
\text { sebuah } \\
\text { perpustakaan } \\
\text { semakin modern } \\
\text { dengan fasilitas } \\
\text { komputer yang }\end{array}$ \\
\hline
\end{tabular}




\begin{tabular}{|c|c|c|c|c|}
\hline No. & $\begin{array}{l}\text { Judul Jurnal } \\
\text { dan Peneliti }\end{array}$ & $\begin{array}{c}\text { Tahun dan } \\
\text { Tempat } \\
\text { Penelitian }\end{array}$ & $\begin{array}{c}\text { Metode } \\
\text { Penelitian }\end{array}$ & Hasil Penelitian \\
\hline & $\begin{array}{l}\text { Sistem Temu } \\
\text { Kembali } \\
\text { Informasi } \\
\text { Berbasis } \\
\text { Digital, oleh } \\
\text { Andi Ibrahim }\end{array}$ & & & $\begin{array}{l}\text { dilengkapi } \\
\text { dengan OPAC } \\
\text { (Online Public } \\
\text { Access Catalogue) } \\
\text { sebagai sarana } \\
\text { untuk menemukan } \\
\text { kembali informasi } \\
\text { yang relevan } \\
\text { dengan cepat dan } \\
\text { tepat.[12] }\end{array}$ \\
\hline 4. & $\begin{array}{l}\text { Aplikasi } \\
\text { Sistem } \\
\text { Informasi } \\
\text { Perpustakaan } \\
\text { Di SMK } \\
\text { Takhassus } \\
\text { Kalibeber } \\
\text { Wonosobo, } \\
\text { oleh Adi } \\
\text { Suwondo }\end{array}$ & $\begin{array}{l}\text { 2014, SMK } \\
\text { Takhassus } \\
\text { Kalibeber } \\
\text { Wonosobo }\end{array}$ & Kuantitatif & $\begin{array}{l}\text { Pada penelitian ini } \\
\text { dibuat sebuah } \\
\text { sistem aplikasi } \\
\text { komputer berbasis } \\
\text { desktop untuk } \\
\text { melakukan } \\
\text { pencatatan } \\
\text { sirkulasi } \\
\text { perpustakaan } \\
\text { untuk } \\
\text { memudahkan staf } \\
\text { perpustakaan } \\
\text { melakukan } \\
\text { transaksi } \\
\text { hariannya.[11] }\end{array}$ \\
\hline 5. & $\begin{array}{l}\text { Perancangan } \\
\text { Aplikasi E- } \\
\text { Library } \\
\text { Menggunakan } \\
\text { Bahasa } \\
\text { Pemrograman } \\
\text { PHP Pada } \\
\text { Universitas } \\
\text { Methodist } \\
\text { Indonesia, } \\
\text { oleh Ambon } \\
\text { Saragih, } \\
\text { Emma Rosinta } \\
\text { Simarmata, } \\
\text { Jhoni Maslan } \\
\end{array}$ & $\begin{array}{l}2015, \\
\text { Universitas } \\
\text { Methodist } \\
\text { Indonesia }\end{array}$ & Kuantitatif & $\begin{array}{l}\text { Penelitian ini } \\
\text { menghasilkan } \\
\text { perubahan } \\
\text { pengolahan data } \\
\text { perpustakaan yang } \\
\text { awalnya berbasis } \\
\text { desktop menjadi } \\
\text { aplikasi E-Library } \\
\text { berbasis Web. } \\
{[10]}\end{array}$ \\
\hline 6. & $\begin{array}{l}\text { Sistem } \\
\text { Informasi } \\
\text { Perpustakaan } \\
\text { Berbasis Web } \\
\text { Dengan } \\
\text { Metode } \\
\text { Prototype: } \\
\text { Studi Kasus } \\
\text { Sekolah Islam } \\
\text { Gema Nurani } \\
\text { Bekasi, oleh } \\
\text { Siti Nurajizah }\end{array}$ & $\begin{array}{l}\text { 2015, Sekolah } \\
\text { Islam Gema } \\
\text { Nurani } \\
\text { Bekasi }\end{array}$ & Kuantitatif & $\begin{array}{l}\text { Penelitian ini } \\
\text { menghasilkan } \\
\text { sebuah sistem } \\
\text { informasi berbasis } \\
\text { web untuk } \\
\text { membantu } \\
\text { memudahkan } \\
\text { proses pendataan } \\
\text { buku, anggota, } \\
\text { dan pembuatan } \\
\text { laporan dapat } \\
\text { diselesaikan } \\
\text { dengan tepat, } \\
\text { cepat dan akurat. } \\
\text { Siswa tidak perlu } \\
\text { dtang } \\
\text { perpustakaan } \\
\text { untuk mendaftar } \\
\text { menjadi anggota. } \\
\text { Disediakan } \\
\text { katalog online } \\
\text { untuk pencarian } \\
\text { buku. [1] }\end{array}$ \\
\hline 7. & $\begin{array}{l}\text { Perancangan } \\
\text { Dan } \\
\text { Penerapan } \\
\text { Sistem } \\
\text { Informasi } \\
\end{array}$ & $\begin{array}{l}\text { 2015, SMAN } \\
5 \text { Kediri }\end{array}$ & Kuantitatif & $\begin{array}{l}\text { Pada penelitian ini } \\
\text { menghasilkan } \\
\text { sistem informasi } \\
\text { perpustakaan } \\
\text { berguna sebagai }\end{array}$ \\
\hline
\end{tabular}

\begin{tabular}{|c|c|c|c|c|}
\hline No. & $\begin{array}{l}\text { Judul Jurnal } \\
\text { dan Peneliti }\end{array}$ & $\begin{array}{c}\text { Tahun dan } \\
\text { Tempat } \\
\text { Penelitian }\end{array}$ & $\begin{array}{l}\text { Metode } \\
\text { Penelitian }\end{array}$ & Hasil Penelitian \\
\hline & \begin{tabular}{lr}
\multicolumn{3}{l}{ Perpustakaan } \\
Sekolah & Pada \\
SMAN & 5 \\
Kediri, oleh \\
Ali Sahab, \\
Windha Mega \\
Pradnya D
\end{tabular} & & & $\begin{array}{l}\text { aplikasi dengan } \\
\text { fungsi manajemen } \\
\text { resource buku- } \\
\text { buku yang ad } \\
\text { diperpustakaan } \\
\text { dan transaksi yang } \\
\text { dilakukan } \\
\text { dilapangan. [13] }\end{array}$ \\
\hline 8. & $\begin{array}{l}\text { Sistem } \\
\text { Informasi } \\
\text { Perpustakaan } \\
\text { Sekolah } \\
\text { Berbasis Web, } \\
\text { oleh Diah } \\
\text { Puspitasari }\end{array}$ & 2016 & Kuantitatif & $\begin{array}{l}\text { Hasil penelitian } \\
\text { ini adalah sistem } \\
\text { informasi } \\
\text { perpustakaan } \\
\text { untuk } \\
\text { mempermudah } \\
\text { anggota dalam } \\
\text { proses pencarian } \\
\text { buku dan } \\
\text { membaca buku } \\
\text { online.[4] }\end{array}$ \\
\hline 9. & $\begin{array}{l}\text { Sistem } \\
\text { Informasi } \\
\text { Perpustakaan } \\
\text { Online } \\
\text { Berbasis Web, } \\
\text { oleh Astria } \\
\text { Firman, Hans } \\
\text { F. Wowor, } \\
\text { Xaverius } \\
\text { Najoan }\end{array}$ & $\begin{array}{l}2016, \\
\text { Universitas } \\
\text { Sam } \\
\text { Ratulangi }\end{array}$ & Kuantitatif & $\begin{array}{l}\text { Penelitian ini } \\
\text { menghasilkan } \\
\text { sistem informasi } \\
\text { Perpustakaan } \\
\text { Online Berbasis } \\
\text { Web yang } \\
\text { digunakan untuk } \\
\text { proses pengolahan } \\
\text { data dan laporan, } \\
\text { mahasiswa dapat } \\
\text { mencari data } \\
\text { buku, informasi } \\
\text { peminjaman buku } \\
\text { dan melakukan } \\
\text { pendaftaran } \\
\text { anggota melalui } \\
\text { jaringan } \\
\text { internet.[5] }\end{array}$ \\
\hline 10. & $\begin{array}{l}\text { Pembuatan } \\
\text { Aplikasi E- } \\
\text { Service } \\
\text { Library Untuk } \\
\text { Pengelolaan } \\
\text { Perpustakaan } \\
\text { Di SMAN } 4 \\
\text { Kota Solok, } \\
\text { oleh Boby Das } \\
\text { Prawira } \\
\text { Negara, } \\
\text { Marlini }\end{array}$ & $\begin{array}{lr}\text { 2018, } & \text { SMA } \\
\text { Negeri } & 4 \\
\text { Solok } & \end{array}$ & Kuantitatif & $\begin{array}{lr}\begin{array}{l}\text { Penelitian } \\
\text { menghasilkan }\end{array} \\
\text { aplikasi } & \\
\text { perpustakaan } & \\
\text { berbasis } & \text { web } \\
\text { application } & \text { yang } \\
\text { hanya } & \text { boleh } \\
\text { digunakan } & \text { oleh } \\
\text { pustakawan } & \\
\text { sekolah } & \text { yang } \\
\text { bertujuan } & \\
\text { melayani } & \\
\text { pemustaka dalam } \\
\text { hal sirkulasi } \\
\text { koleksi } \\
\text { perpustakaan } \\
\text { sekolah.[9] }\end{array}$ \\
\hline
\end{tabular}

Perbedaan dengan penelitian sebelumnya adalah dalam proses peminjamannya bisa menggunakan Barcode Scanner dan siswa juga dapat membaca ebook yang tersedia ketika sudah menjadi anggota.

Pada penelitian ini penulis telah menganalisa kebutuhan apa saja yang diinginkan oleh SMP Negeri 3 Kota Bekasi sebagai tahapan awal. Hasilnya pada website ini mempunyai 2 (dua) akses, yaitu admin dan siswa. akses yang pertama adalah admin, adapun yang dapat dilakukan oleh admin adalah sebagai berikut: dapat melakukan akses keseluruh sistem informasi perpustakaan, seperti: mengakses halaman login,

ISSN $: 2301-7988$

E-ISSN : 2581-0588

DOI $: 10.32736 /$ sisfokom.v8i2.657 
pengelolaan buku, data buku, register keanggotaan, data keanggotaan, peminjaman buku, pengembalian buku, dan denda. Sedangkan untuk siswa yang dapat dilakukan dalam sistem informasi ini yaitu: mengakses halaman login, peminjaman buku, Ebook digital, ebook non digital.

Selain membedakan penggunaan program berdasarkan kewenangan, program juga memerlukan kebutuhan secara fungsional, yang diantaranya:

a. Sistem informasi mampu membedakan Administrator dan User saat melakukan Login.

b. Sistem informasi memberi kemudahan dalam mengelola data master (yang meliputi data anggota, data petugas dan data buku).

c. Program memberi kemudahan dalam menginput data peminjaman dan pengembalian.

d. Program memberi kemudahan dalam menghitung denda yang dikenakan, baik terhadap keterlambatan pengembalian buku, menghilangkan buku, atau merusak buku.

Tahapan kedua mendesain database menggunakan Entity Relationship Diagram (ERD), yang digambarkan sebagai berikut:

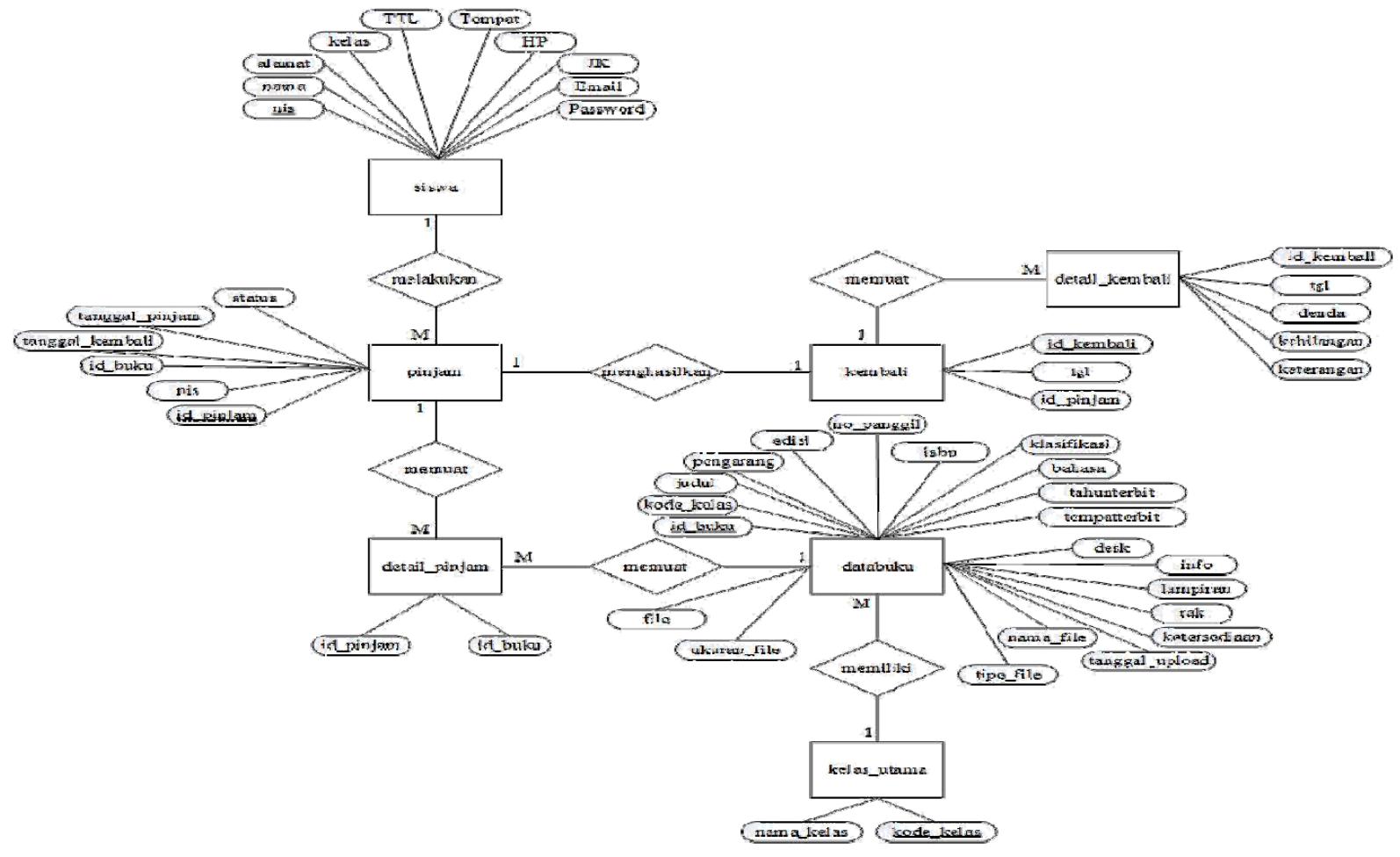

Sumber: Penelitian (2019)

Gambar 1. Entity Relationship Diagram

Rancangan struktur navigasi dibagi menjadi navigasi admin dan siswa. Berikut gambar dari struktur navigasi admin:

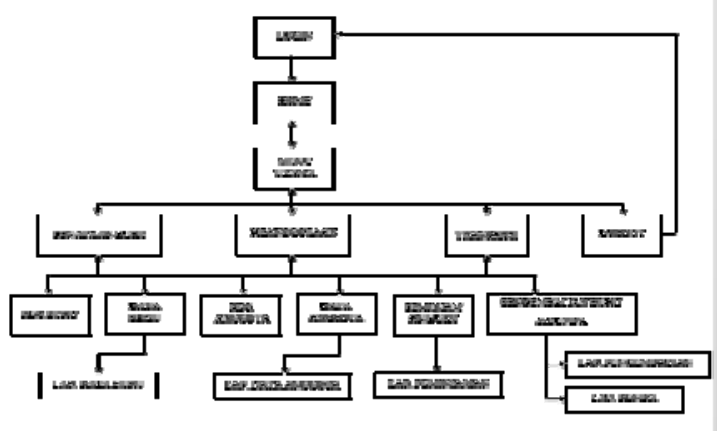

Sumber: Penelitian (2019)

Gambar 3. Struktur Navigasi Admin
Sedangkan struktur navigasi siswa digambarkan sebagai berikut:

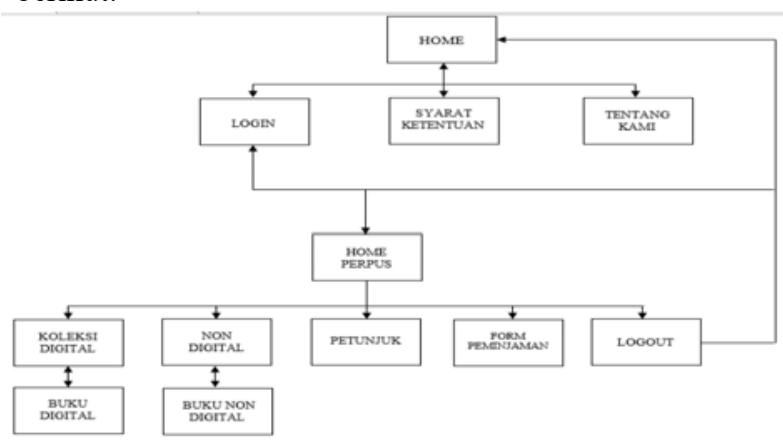

Sumber: Penelitian (2019)

Gambar 4. Struktur Navigasi Siswa

ISSN : :2301-7988

E-ISSN : 2581-0588

DOI : $10.32736 /$ sisfokom.v8i2.657 
Implementasi rancangan antar muka pada sistem informasi perpustakaan berdasarkan hasil rancangan antar muka.

1. Halaman Home

Rancangan Home berisikan informasi seputar SMP Negeri 3 Kota Bekasi.

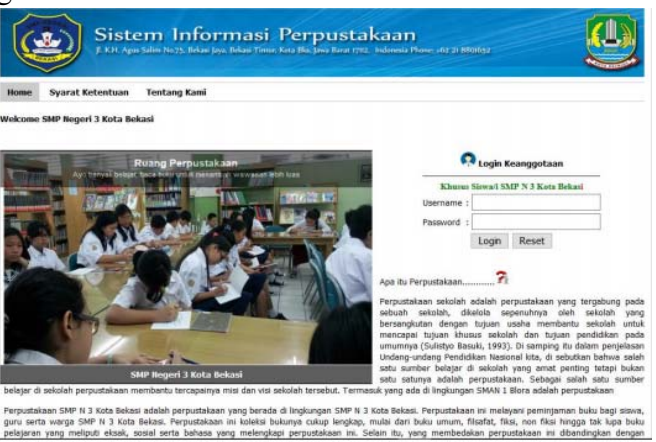

Sumber: Penelitian (2019)

Gambar 5. Halaman Home

2. Register Book

Pada halaman ini admin bertugas untuk melakukan penginput data buku sesuai dengan identitas buku.

\section{Register Book}

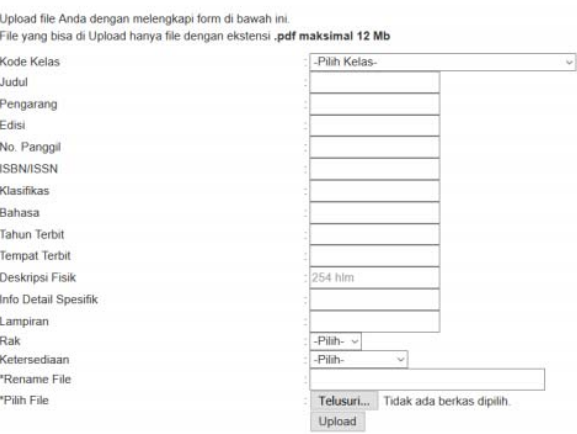

Sumber: Penelitian (2019)

Gambar 6. Halaman Register Book

3. Laporan Data Buku

Pada halaman ini admin dapat melihat hasil dan mencetak data buku.

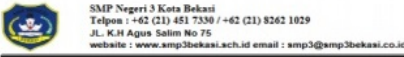

Laporan Data Buku

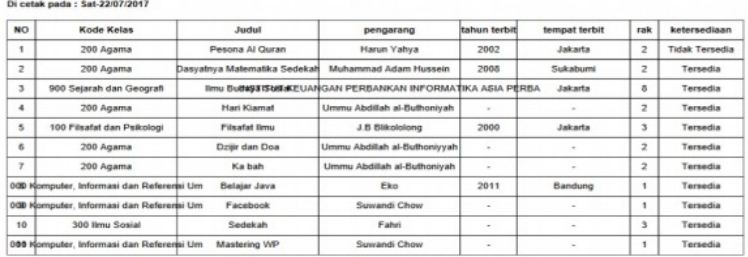

Sumber: Penelitian (2019)

Gambar 7. Laporan Data Buku
4. Halaman Register Anggota

Admin melakukan register anggota sesuai dengan identitas siswa untuk mendapatkan login.

\section{Register Anggota}
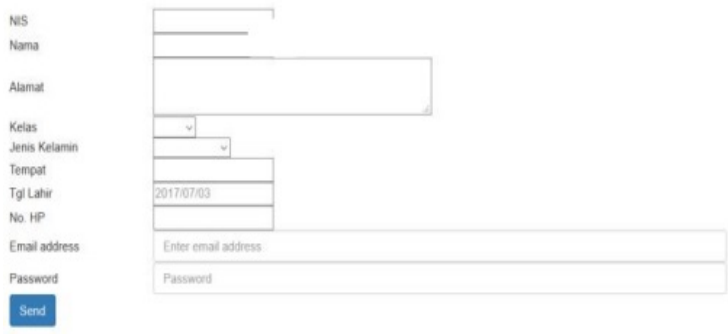

Sumber: Penelitian (2019)

Gambar 8. Halaman Register Anggota

5. Laporan Data Anggota

Pada halaman ini admin dapat melihat hasil dan mencetak data identitas siswa.

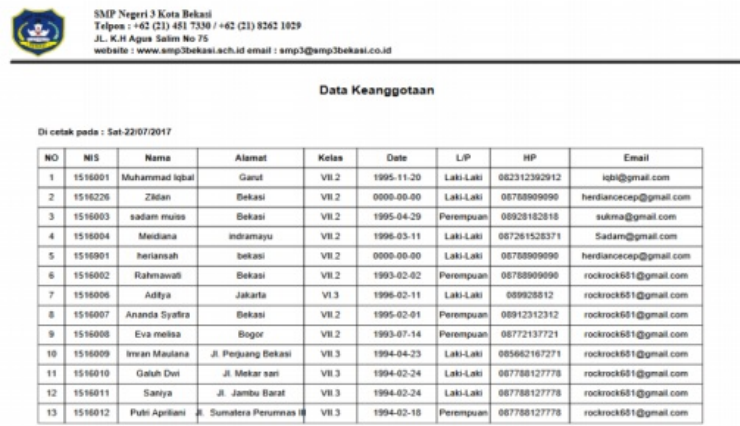

Sumber: Penelitian (2019)

Gambar 9. Laporan Data Anggota

6. Halaman Peminjaman Buku Anggota

Siswa dapat melakukan peminjaman buku secara online dengan mengisi form yang sudah disediakan pada website.

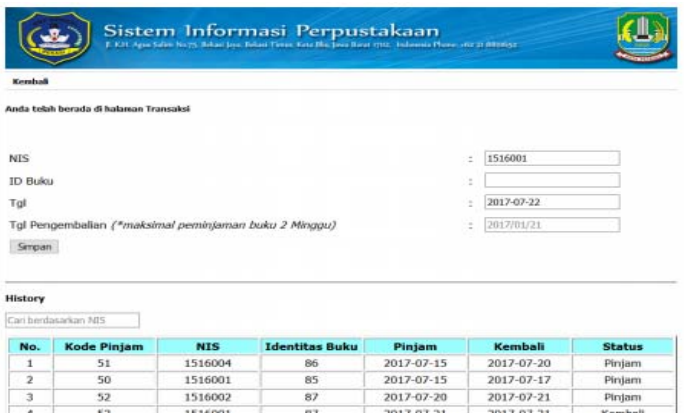

Sumber: Penelitian (2019)

Gambar 10. Laporan Data Anggota

7. Laporan Data Peminjaman Buku

Admin dapat melihat hasil data transaksi buku dan mencetak data peminjaman buku yang masuk.

ISSN $: 2301-7988$

E-ISSN : 2581-0588

DOI $: 10.32736 /$ sisfokom.v8i2.657 


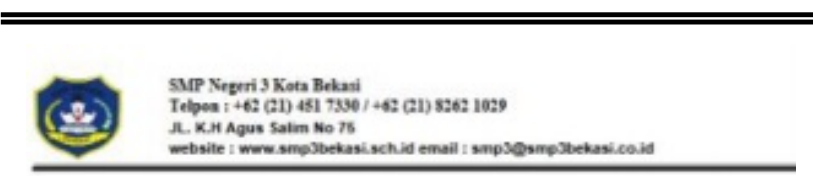

Data Peminjaman

\begin{tabular}{|c|c|c|c|c|c|}
\hline no & 10 Pinion & Nes & ID Buks & Tanosal Aniam & Tanove: nemeat \\
\hline 1 & 51 & 1516004 & o6 & 2017.97 .45 & $2017-07.20$ \\
\hline 2 & so & 1516001 & ss & 2017.07 .15 & 2017.07 .17 \\
\hline 3 & 52 & 1516002 & 87 & $2017-47.20$ & $2017-07-21$ \\
\hline 4 & 53 & 1516001 & 87 & $2017-07-21$ & $2017-97-31$ \\
\hline 5 & 54 & 1516001 & 85 & $2017-97-21$ & $2017-07-22$ \\
\hline
\end{tabular}

Sumber: Penelitian (2019)

Gambar 11. Laporan Data Peminjaman Buku

8. Halaman Pengembalian Buku

Admin dapat mengetahui data buku yang telah dikembalikan dan dapat mencari data sampai dengan detail buku yang dikembalikan oleh siswa.

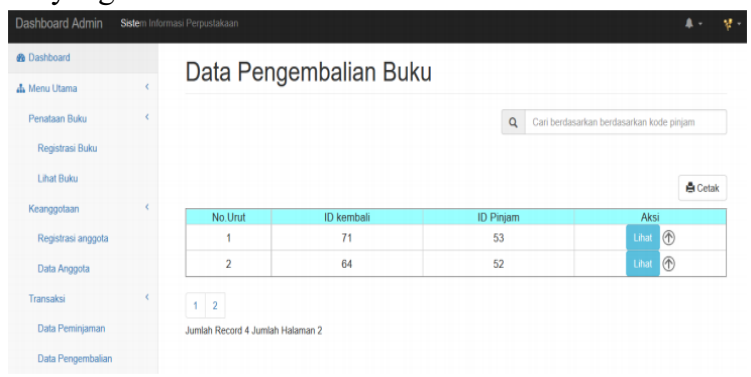

Sumber: Penelitian (2019)

Gambar 12. Halaman Data Pengembalian Buku

9. Laporan Pengembalian Buku

Admin dapat mengetahui data buku yang telah dikembalikan dan dapat mencetak hasil data pengembalian buku.

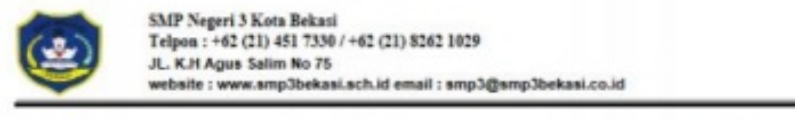

Laporan Data Pengembalian Buku

\begin{tabular}{|c|c|c|c|}
\hline no & 10 Kembali & ID Piniam & Tal. Kembal \\
\hline 1 & $\pi$ & 53 & $2017-07-21$ \\
\hline 2 & 64 & 52 & $2017-07-21$ \\
\hline 3 & 76 & 52 & $2017-07.21$ \\
\hline 4 & 60 & so & 2017.07 .46 \\
\hline
\end{tabular}

Sumber: Penelitian (2019)

Gambar 13. Laporan Data Pengembalian Buku

10. Koleksi Digital

Pada halaman ini siswa dapat membaca koleksi digital dan juga bisa mendownload buku tersebut.

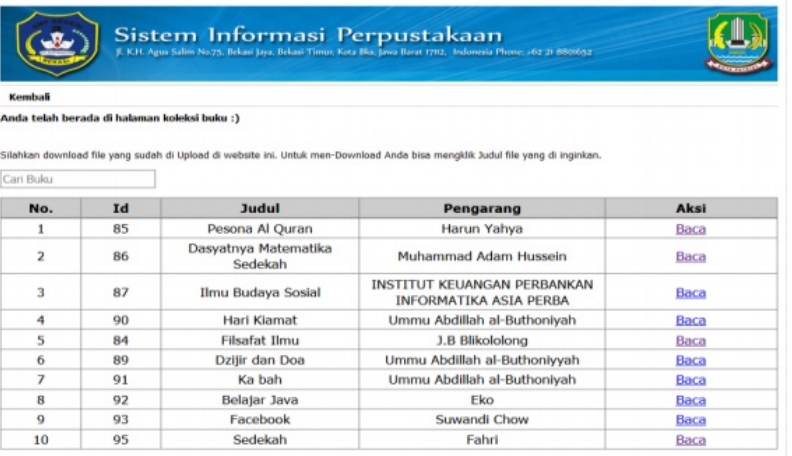

Sumber: Penelitian (2019)

Gambar 11. Halaman Koleksi Digital

Setelah pembuatan sistem informasi perpustakaan berbasis web dilakukan pengujian sistem menggunakan blackbox testing yang diuraikan sebagai berikut:

Tabel 2. Hasil Blackbox Testing Halaman Login Admin

\begin{tabular}{|c|c|c|c|c|c|}
\hline No. & $\begin{array}{c}\text { Skenario } \\
\text { Unit }\end{array}$ & Test Case & $\begin{array}{c}\text { Hasil yang } \\
\text { diharapkan }\end{array}$ & $\begin{array}{c}\text { Hasil } \\
\text { Pengujian }\end{array}$ & Kesimpulan \\
\hline 1 & $\begin{array}{l}\text { Username } \\
\text { dan } \\
\text { password } \\
\text { tidak diisi } \\
\text { kemudian } \\
\text { klik } \\
\text { tombol } \\
\text { login }\end{array}$ & $\begin{array}{l}\text { Username } \\
\text { : kosong) } \\
\text { Password: } \\
\text { (kosong) }\end{array}$ & $\begin{array}{l}\text { Sistem akan } \\
\text { menolak } \\
\text { akses user } \\
\text { dan } \\
\text { menampilkan } \\
\text { "Data Tidak } \\
\text { Boleh } \\
\text { Kosong" }\end{array}$ & $\begin{array}{c}\text { Sesuai } \\
\text { harapan }\end{array}$ & Valid \\
\hline 2 & $\begin{array}{l}\text { Mengetikk } \\
\text { an } \\
\text { Username } \\
\text { dan } \\
\text { password } \\
\text { tidak diisi } \\
\text { atau } \\
\text { kosong } \\
\text { kemudian } \\
\text { klik } \\
\text { tombol } \\
\text { login }\end{array}$ & $\begin{array}{l}\text { Username: } \\
\text { admin } \\
\text { Password: } \\
\text { (kosong) }\end{array}$ & $\begin{array}{l}\text { Sistem akan } \\
\text { menolak } \\
\text { akses user } \\
\text { dan } \\
\text { menampilkan } \\
\text { "Username } \\
\text { atau } \\
\text { Password } \\
\text { Salah, } \\
\text { Periksa } \\
\text { Kembali" }\end{array}$ & $\begin{array}{c}\text { Sesuai } \\
\text { harapan }\end{array}$ & Valid \\
\hline 3 & $\begin{array}{l}\text { Username } \\
\text { tidak diisi } \\
\text { (kosong) } \\
\text { dan } \\
\text { password } \\
\text { diisi } \\
\text { kemudian } \\
\text { klik } \\
\text { tombol } \\
\text { login }\end{array}$ & $\begin{array}{l}\text { Username: } \\
\text { (kosong) } \\
\text { Password: } \\
\text { admin }\end{array}$ & $\begin{array}{l}\text { Sistem akan } \\
\text { menolak } \\
\text { akses user } \\
\text { dan } \\
\text { menampilkan } \\
\text { "Username } \\
\text { atau } \\
\text { Password } \\
\text { Salah, } \\
\text { Periksa } \\
\text { kembali" dan } \\
\text { "Data Tidak } \\
\text { Boleh } \\
\text { Kosong" }\end{array}$ & $\begin{array}{c}\text { Sesuai } \\
\text { harapan }\end{array}$ & Valid \\
\hline 4 & $\begin{array}{l}\text { Mengetikk } \\
\text { an salah } \\
\text { satu } \\
\text { kondisi } \\
\text { salah pada } \\
\text { username } \\
\text { atau } \\
\text { password } \\
\text { kemudian } \\
\text { klik } \\
\text { tombol } \\
\text { login }\end{array}$ & $\begin{array}{l}\text { Username: } \\
\text { admin(ben } \\
\text { ar) } \\
\text { Password: } \\
\text { raisa(salah } \\
\text { ) }\end{array}$ & $\begin{array}{l}\text { Sistem akan } \\
\text { menolak } \\
\text { akses user } \\
\text { dan } \\
\text { menampilkan } \\
\text { "Username } \\
\text { dan Password } \\
\text { Salah, } \\
\text { Periksa } \\
\text { kembali" }\end{array}$ & $\begin{array}{c}\text { Sesuai } \\
\text { harapan }\end{array}$ & Valid \\
\hline 5 & $\begin{array}{l}\text { Mengetikk } \\
\text { an salah } \\
\text { satu }\end{array}$ & $\begin{array}{l}\text { Username: } \\
\text { admin12 } \\
\text { (salah) }\end{array}$ & $\begin{array}{l}\text { Sistem akan } \\
\text { menolak } \\
\text { akses user }\end{array}$ & $\begin{array}{c}\text { Sesuai } \\
\text { harapan }\end{array}$ & Valid \\
\hline
\end{tabular}

ISSN $: 2301-7988$

E-ISSN : 2581-0588

DOI $\quad: 10.32736 /$ sisfokom.v8i2.657 


\begin{tabular}{|c|c|c|c|c|c|}
\hline No. & $\begin{array}{c}\text { Skenario } \\
\text { Unit }\end{array}$ & Test Case & $\begin{array}{l}\text { Hasil yang } \\
\text { diharapkan }\end{array}$ & $\begin{array}{c}\text { Hasil } \\
\text { Pengujian }\end{array}$ & Kesimpulan \\
\hline & $\begin{array}{l}\text { kondisi } \\
\text { salah pada } \\
\text { username } \\
\text { atau } \\
\text { password } \\
\text { kemudian } \\
\text { klik } \\
\text { tombol } \\
\text { login }\end{array}$ & $\begin{array}{l}\text { Password: } \\
\text { Admin(be } \\
\text { nar) }\end{array}$ & $\begin{array}{l}\text { dan } \\
\text { menampilkan } \\
\text { "Username } \\
\text { dan Password } \\
\text { Salah, } \\
\text { Periksa } \\
\text { kembali" }\end{array}$ & & \\
\hline 6 & $\begin{array}{l}\text { Mengetikk } \\
\text { an } \\
\text { username } \\
\text { dan } \\
\text { password } \\
\text { dengan } \\
\text { data yang } \\
\text { benar } \\
\text { kemudian } \\
\text { klik } \\
\text { tombol } \\
\text { login }\end{array}$ & $\begin{array}{l}\text { Username: } \\
\text { admin(ben } \\
\text { ar) } \\
\text { Password: } \\
\text { admin(ben } \\
\text { ar) }\end{array}$ & $\begin{array}{l}\text { Sistem } \\
\text { menerima } \\
\text { akses login } \\
\text { dan } \\
\text { kemudian } \\
\text { langsung } \\
\text { menampilkan } \\
\text { home admin. }\end{array}$ & $\begin{array}{l}\text { Sesuai } \\
\text { harapan }\end{array}$ & Valid \\
\hline
\end{tabular}

Tabel 3. Hasil Blackbox Testing Halaman Peminjaman

\begin{tabular}{|c|c|c|c|c|c|}
\hline No. & $\begin{array}{c}\text { Skenario } \\
\text { Unit }\end{array}$ & Test Case & $\begin{array}{c}\text { Hasil yang } \\
\text { diharapkan }\end{array}$ & $\begin{array}{c}\text { Hasil } \\
\text { Pengujian }\end{array}$ & Kesimpulan \\
\hline 1 & $\begin{array}{l}\text { Siswa } \\
\text { mengisika } \\
\mathrm{n} \text { form } \\
\text { peminjama } \\
\mathrm{n} \text { buku lalu } \\
\text { menekan } \\
\text { simpan }\end{array}$ & $\begin{array}{l}\text { NIS: } \\
\text { 1516001 } \\
\text { ID Buku: } \\
41 \\
\text { Tgl hari } \\
\text { ini : } \\
20 / 01 / 201 \\
6 \text { Tgl } \\
\text { pengembal } \\
\text { ian: } \\
20 / 01 / 201 \\
6\end{array}$ & $\begin{array}{l}\text { Sistem akan } \\
\text { memproses } \\
\text { dan } \\
\text { menyimpan } \\
\text { ke } \\
\text { database “ } \\
\text { data telah } \\
\text { dikirim" }\end{array}$ & $\begin{array}{l}\text { Sesuai } \\
\text { harapan }\end{array}$ & Valid \\
\hline 2 & $\begin{array}{l}\text { Siswa } \\
\text { mengisika } \\
\mathrm{n} \text { form } \\
\text { peminjama } \\
\mathrm{n} \text { buku lalu } \\
\text { menekan } \\
\text { simpan }\end{array}$ & $\begin{array}{l}\text { NIS: } \\
\text { 1516001 } \\
\text { ID Buku: } \\
\text { (kosong) } \\
\text { Tgl hari } \\
\text { ini : } \\
20 / 01 / 201 \\
7 \\
\text { Tgl } \\
\text { pengembal } \\
\text { ian : } \\
\text { (kosong) }\end{array}$ & $\begin{array}{l}\text { Sistem tidak } \\
\text { akan } \\
\text { memproses } \\
\text { dan } \\
\text { menampilkan } \\
\text { "Masukan } \\
\text { ID Buku" }\end{array}$ & $\begin{array}{l}\text { Sesuai } \\
\text { harapan }\end{array}$ & Valid \\
\hline 3 & $\begin{array}{l}\text { Siswa } \\
\text { mengisika } \\
\mathrm{n} \text { form } \\
\text { peminjama } \\
\mathrm{n} \text { buku lalu } \\
\text { menekan } \\
\text { simpan }\end{array}$ & $\begin{array}{l}\text { NIS: } \\
1516001 \\
\text { ID Buku: } \\
85 \\
\text { Tgl hari } \\
\text { ini : } \\
20 / 01 / 201 \\
7 \text { Tgl } \\
\text { pengembal } \\
\text { ian: } \\
\text { (kosong) }\end{array}$ & $\begin{array}{l}\text { Sistem tidak } \\
\text { akan } \\
\text { memproses } \\
\text { dan } \\
\text { menampilkan } \\
\text { "Masukan } \\
\text { Tanggal" }\end{array}$ & $\begin{array}{l}\text { Sesuai } \\
\text { harapan }\end{array}$ & Valid \\
\hline
\end{tabular}

Tabel 4. Hasil Blackbox Testing Halaman Register Anggota

\begin{tabular}{|c|c|c|c|c|c|}
\hline No. & $\begin{array}{c}\text { Skenario } \\
\text { Unit }\end{array}$ & Test Case & $\begin{array}{r}\text { Hasil yang } \\
\text { diharapkan }\end{array}$ & $\begin{array}{c}\text { Hasil } \\
\text { Pengujian }\end{array}$ & Kesimpulan \\
\hline 1 & $\begin{array}{l}\text { Admin } \\
\text { tidak } \\
\text { menuliska } \\
\text { n identitas } \\
\text { siswa pada } \\
\text { teksbox } \\
\text { lalu klik } \\
\text { send }\end{array}$ & 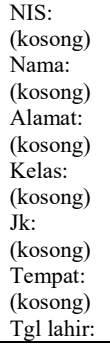 & $\begin{array}{l}\text { Sistem tidak } \\
\text { akan } \\
\text { memproses } \\
\text { dan } \\
\text { menampilkan } \\
\text { "data tidak } \\
\text { boleh } \\
\text { kosong" }\end{array}$ & $\begin{array}{l}\text { Sesuai } \\
\text { harapan }\end{array}$ & Valid \\
\hline
\end{tabular}

\begin{tabular}{|c|c|c|c|c|c|}
\hline No. & $\begin{array}{c}\text { Skenario } \\
\text { Unit }\end{array}$ & Test Case & $\begin{array}{c}\text { Hasil yang } \\
\text { diharapkan }\end{array}$ & $\begin{array}{c}\text { Hasil } \\
\text { Pengujian }\end{array}$ & Kesimpulan \\
\hline & & $\begin{array}{l}\text { (kosong) } \\
\text { No hp: } \\
\text { (kosong) } \\
\text { Email: } \\
\text { (kosong) } \\
\text { Password:( } \\
\text { kosong) }\end{array}$ & & & \\
\hline 2 & $\begin{array}{l}\text { Admin } \\
\text { menuliska } \\
\text { n identitas } \\
\text { siswa pada } \\
\text { teksbox } \\
\text { lalu klik } \\
\text { send }\end{array}$ & $\begin{array}{l}\text { NIS: } \\
\text { 1516001 } \\
\text { Nama: } \\
\text { iqbal } \\
\text { Alamat: } \\
\text { bekasi } \\
\text { Kelas: VI } \\
2 \\
\text { Jk: Laki- } \\
\text { laki } \\
\text { Tempat: } \\
\text { bekasi Tgl } \\
\text { lahir: } \\
\text { 26/03/199 } \\
\text { 2 No hp: } \\
\text { 087721212 } \\
\text { Email: } \\
\text { iqbal@gm } \\
\text { ail.com } \\
\text { Password:i } \\
\text { qbal }\end{array}$ & $\begin{array}{l}\text { Sistem akan } \\
\text { memproses } \\
\text { password } \\
\text { akan } \\
\text { otomatis } \\
\text { dikirimkan } \\
\text { sesuai } \\
\text { dengan } \\
\text { email yang } \\
\text { dituliskan }\end{array}$ & $\begin{array}{r}\text { Sesuai } \\
\text { harapan }\end{array}$ & Valid \\
\hline 3 & $\begin{array}{l}\text { Admin } \\
\text { menuliska } \\
\text { n identitas } \\
\text { siswa pada } \\
\text { teksbox } \\
\text { lalu klik } \\
\text { send }\end{array}$ & $\begin{array}{l}\text { NIS: } \\
\text { 1516001 } \\
\text { Nama: } \\
\text { iqbal } \\
\text { Alamat: } \\
\text { bekasi } \\
\text { Kelas: VI } \\
2 \\
\text { Jk: Laki- } \\
\text { laki } \\
\text { Tempat: } \\
\text { bekasi } \\
\text { Tgl lahir: } \\
\text { 26/03/199 } \\
2 \\
\text { No hp: } \\
087721212 \\
\text { Email:(kos } \\
\text { ong) } \\
\text { Password:( } \\
\text { asd) }\end{array}$ & $\begin{array}{l}\text { Sistem tidak } \\
\text { akan } \\
\text { memproses } \\
\text { "masukan } \\
\text { alamat } \\
\text { email" }\end{array}$ & $\begin{array}{c}\text { Sesuai } \\
\text { harapan }\end{array}$ & Valid \\
\hline 4 & $\begin{array}{l}\text { Admin } \\
\text { menuliska } \\
\text { n identitas } \\
\text { siswa pada } \\
\text { teksbox } \\
\text { lalu klik } \\
\text { send }\end{array}$ & $\begin{array}{l}\text { NIS: } \\
\text { 1516001 } \\
\text { Nama: } \\
\text { iqbal } \\
\text { Alamat: } \\
\text { bekasi } \\
\text { Kelas: VI } \\
\text { 2 } \\
\text { Jk: Laki- } \\
\text { laki } \\
\text { Tempat: } \\
\text { bekasi } \\
\text { Tgl lahir: } \\
\text { 26/03/199 } \\
2 \\
\text { No hp: } \\
\text { 087721212 } \\
\text { Email:(roc } \\
\text { krock681 } \\
\text { @gmail.co } \\
\text { m) } \\
\text { Password:( } \\
\text { kosong) }\end{array}$ & $\begin{array}{l}\text { Sistem tidak } \\
\text { akan } \\
\text { memproses } \\
\text { "password } \\
\text { tidak boleh } \\
\text { kosong" }\end{array}$ & $\begin{array}{c}\text { Sesuai } \\
\text { harapan }\end{array}$ & Valid \\
\hline
\end{tabular}

\section{PENUTUP}

Berdasarkan penelitian yang dilakukan dengan mengamati dan menganalisa sistem dan penelitian terdahulu

ISSN : 2301-7988

E-ISSN : 2581-0588

DOI $: 10.32736 /$ sisfokom.v8i2.657 
maka dapat disimpulkan bahwa penelitian pada SMP Negeri 3 Kota Bekasi menghasilkan sebuah sistem informasi perpustakaan berbasis website yang diujikan menggunakan blackbox testing sehingga dengan adanya sistem informasi ini akan mempermudah petugas dan anggota perpustakaan dalam melakukan kegiatan peminjaman buku di perpustakaan serta anggota perpustakaanpun dapat mengetahui buku apa saja yang tersedia di perpustakaan dan membaca serta mendownload koleksi digital.

\section{DAFTAR PUSTAKA}

[1] S. Nurajizah, "Sistem Informasi Perpustakaan Berbasis WEB dengan Metode Prototype: Studi Kasus Sekolah Islam Gema Nurani Bekasi," Semin. Nas. Inov. dan Tren 2015, vol. 179, no. 6, pp. 1643-1644, 2015.

[2] F. Nugraha, "Analisa dan perancangan sistem informasi perpustakaan,” J. Simetris, vol. 5, no. 1, pp. 27-32, 2014.

[3] R. Cahyaningtyas and I. Siska, "Perancangan Sistem Informasi Perpustakaan Pada Smp Negeri 3 Tulakan, Kecamatan Tulakan Kabupatean Pacitan," Indones. J. Netw. Secur., vol. 4, no. 2, pp. 15-20, 2015.

[4] D. Puspitasari, "SISTEM INFORMASI PERPUSTAKAAN SEKOLAH BERBASIS WEB," J. Pilar Nusa Mandiri, vol. XII, no. 2, pp. 227-240, 2016.

[5] A. Firman, H. F. Wowor, and X. Najoan, "Sistem Informasi Perpustakaan Online Berbasis Web," E-journal Tek. Elektro dan Komput., vol. 5, no. 2, pp. 29-36, 2016.

[6] R. S. Pressman, Rekayasa Perangkat Lunak Pendekatan Praktisi (Buku I). Yogyakarta: Andi Publisher, 2007.

[7] M. Sukamto, Rosa Ariani Shalahuddin, Modul Pembelajaran Rekayasa Perangkat Lunak Terstruktur dan Berorientasi Objek. Bandung: Informatika Bandung, 2016.

[8] I. Binanto, Multimedia Digital-Dasar Teori dan Pengembangannya. Yogyakarta: Andi Offset, 2010.

[9] B. D. P. Negara and M. Marlini, "Pembuatan Aplikasi E-Service Library Untuk Pengelolaan Perpustakaan Di SMA N 4 Kota Solok," J. Ilmu Inf. Perpust. Dan Kearsipan, vol. 6, no. 2, pp. 1$11,2018$.

[10] A. Saragih, E. Rosinta, and S. Jhoni, "Perancangan Aplikasi ELibrary Menggunakan Bahasa Pemrograman PHP Pada Universitas Methodist Indonesia," Times, vol. IV, no. 1, pp. 31$35,2015$.

[11] A. Suwondo, "Aplikasi Sistem Informasi Perpustakaan di SMK Takhassus Kalibeber Wonosobo," J. PPKM UNSIQ, pp. 31-39, 2014.

[12] I. Andi, "Konsep Dasar Manajemen Perpustakaan Dalam Mewujudkan Mutu Layanan Prima Dengan Sistem Temu Kembali Informasi Berbasis Digital," Khizanah Al-hikmah, vol. 2, pp. 129 138, 2014.

[13] A. Sahab and W. Pradnya D, "Perancangan Dan Penerapan Sistem Informasi Perpustakaan Sekolah Pada Sman 5 Kediri," Data Manaj. dan Teknol. Inf., vol. 16, no. 1, p. 8, 2015.

[14] S. Mujilahwati and S. Muhtadin, "Sistem Manajemen Perpustakaan ( Online ) Pada Smp 'Empat Lima' 2 Kedungpring Lamongan," J. Tek., vol. 6, no. Laporan TA 2013, pp. 01-04, 2014.

[15] D. E. Hendrianto, "Pembuatan Sistem Informasi Perpustakaan Berbasis Website Pada Sekolah Menegah Pertama Negeri 1 Donorojo Kabupaten Pacitan," Indones. J. Netw. Secur., vol. 3, no. 4, pp. 57-64, 2014.

ISSN : 2301-7988

E-ISSN : 2581-0588

DOI : $10.32736 /$ sisfokom.v8i2.657 